\title{
Pengaruh Fundamental Makro Dan Pengungkapan Tanggung Jawab Sosial Islam Terhadap Nilai Perusahaan Melalui Pendapat Audit Atas Kelangsungan Usaha (Pada Bank Syariah Milik Negara Indonesia2016-2020)
}

\author{
Dinda Dwi Wardani \\ Institut Pesantren KH Abdul Chalim, Mojokerto, Indonesia \\ Email :dindawrdni@gmail.com, \\ Lu'Lu' IlMaknuun \\ Institut Pesantren KH Abdul Chalim, Mojokerto, Indonesia \\ Email :luluilmaknuun92@gmail.com, \\ Ahmad Mukhlisuddin \\ Institut Pesantren KH Abdul Chalim, Mojokerto, Indonesia \\ Email :muhlisuddinamou@gmail.com,
}

\begin{abstract}
This study aims to examine and analyze the relationship between The Influence of Fundamental Macro and Islamic Coorporate Social Responsibility Disclosure towards Value of the Firm Through Auditor's Opinion Going Concern On the enterprise sustainability as Variable Intervening (Case in Governmental Shariah Banks 2016-2020). Research population at 4 State Owned Banking Shariah Enterprise Indonesia, this research method uses purposive sampling with companies in 2016-2020. The techniques of data analysis in this study using Partial Least Square (PLS) consist of inner model, outer model and weight relation. The test result showed that 4 tested variables were influences by other variabels and were significant with t-statistic above significant level with t-tabel 1,960, except Disclousure Of Corporate Social Islam Responsibility against Audit Opinion Going Concern showing the effect -0.683 t-statistic 1.027 so the research hypothesis (H3) of Disclousure Of Corporate Social Islam Responsibility has not significant effect on Audit Opinion Going Concern showing the effect is rejected whereas hypothesis other research accepted.
\end{abstract}

Key words : Fundamental Macro, Islamic Coorporate SocialResponsibility, Value of the firm and Audit Opinion Going Concern.

\begin{abstract}
Abstrak
Penelitian ini bertujuan untuk menguji dan menganalisis hubungan antara variabelvariabel yakni fundamental makro dan pengungkapan tanggung jawab sosial islam terhadap nilai perusahaan melalui pendapat audit atas kelangsungan usaha pada bank syariah milik negara Indonesia. populasi penelitian ini terdapat 4 bank syariah milik negara Indonesia, metode penelitian ini mengunakan Teknik purposive sampling dari tahun 2016-2020 . penelitian ini mengunakan Teknik analisis data dengan alat Partial Least Square (PLS) yang menguji pengukuran model, struktural model, dan hubungan variabel. Hasil penelitian menunjukan bahwa terdapat 4 hubungan variabel yang berpengaruh terhadap variabel lainya dengan tingkat signifikan t-statistik diatas 1,96, terkecuali hubungan pengungkapan tanggung jawab sosial islam terhadap pendapat audit atas kelangsungan usaha yang menunjukan nilai t-statistik sebesar 1.027dan nilai 0,sampel sebesar -0.683. Hasil ini menunjukan bahwa hipotesis ketiga (H3) ditolak
\end{abstract}


Dinda Dwi W, Lu'Lu'Il Maknuun, Ahmad Mukhlisuddin : Pengaruh Fundamental Makro...

serta menyatakan bahwa hubungan variabel tersebut tidak berpengaruh negatif signifikan sedangkan hipotesis lainya diterima.

Kata Kunci :Pengungkapan Tanggung Jawab Sosial, Nilai Perusahaan, Pendapat Auditor Atas Kelangsungan Usaha

\section{A. Pendahuluan}

Badan Usaha Milik Negara (BUMN) merupakan perusahaan milik pemerintah yang bergerak sebagai pelaku kegiatan ekonomi ${ }^{1}$. Secara manajerial kegiatan usaha BUMN diatur dan diawasi sesuai dengan kebijakan Kementerian, dimana hal itu menjadikan kelemahan perusahaan dalam mengungkapkan kegiatan operasional usahanya kepada pihak yang membutuhkan². Kegiatan ekonomi BUMN diwujudkan dalam kegiatan usaha, peran BUMN diwujudkan dalam kegiatan usaha yang hampir pada seluruh sektor industri, salah satu sektor yang dilaksanakan ialah sektor keuangan dan perbankan. dimana sektor perbankan menjadi peranan penting dalam pembangunan perekonomian Indonesia ${ }^{3}$. Perbankan Syariah ialah salah satu bagian usaha BUMN dibidang sektor keuangan yang menjadi komponen utama dalam pergerakan ekonomi dengan fungsi intermediasi serta menjalankan kegiatanya dengan prinsip Syariah ${ }^{4}$. Pelaksanaan prinsip Syariah pada perbankan dijelaskan pada undang-undang pasal 18 No 21 tahun 2008 yang berisi ${ }^{5}$ : Prinsip Syariah ialah aturan perjanjian yang memiliki landasan hukum islam pada transaksi diantara kedua belah pihak atau lebih yaitu pihak bank dan pihak nasabah dalam menjalankan kegiatan usahanya ataupun operasionalnya yang sesuai dengan prinsip Syariah, antara lain penyaluran pembiayaan berdasarkan prinsip bagi hasil (Mudharabah), pembiayaan dengan prinsip penyertaan modal (Musharakah), prinsip jual beli barang berdasarkan prinsip sewa (Ijarah) apabila adanya pemindahaan kepemilikan atas barang maka (Ijarah wa iqtina).

Kebijakan ini menunjukan karateristik sistem perbankan Syariah yang beroperasi dengan prinsip bagi hasil, prinsip bagi hasil dapat memberikan alternatif simbiosis mutualisme bagi masyarakat dan bank, karena prinsip tersebut menunjukan investasi yang beretika dan mengedepankan keadilan dalam setiap usahanya ${ }^{6}$. Usaha yang dijalankan Syariah bertujuan mengoptimalisasikan nilai perusahaan, sebab nilai perusahaan mencerminkan keadaan perusahaan yang dapat dihargai oleh investor ${ }^{7}$.

\footnotetext{
${ }^{1}$ Undang-Undang Republik Indonesia No 19 Tahun 2003, Tentang Badan Usaha Milik Negara, PENJELASAN (kemenkeu.go.id), diakses pada tanggal 05 April 2021

${ }^{2}$ Hwihanus, Ratnawati Tri, Yuhertiana Indrawati, Analysis of the Influence of Fundamental Macro and Fundamental Micro to Discolure of Corporate Social Responsibility, Ownership Structure, Financial Performance, Going Concern Audit Opinion and Value of the Firm at State Owned Enterprises in Indonesia, 2018

${ }^{3}$ Undang-Undang Republik Indonesia No 19 Tahun 2003, Tentang Badan Usaha Milik Negara, PENJELASAN (kemenkeu.go.id), diakses pada tanggal 05 April 2021

${ }^{4}$ Kasmir, Bank dan Lembaga keuangan Syariah, (Jakarta: PT. Raja Grafindo Persada, 2009), Hal 24

${ }^{5}$ Undang-Undang Republik Indonesia Nomor 21 tahun 2008 tentang perbankan syariah.

${ }^{6}$ Otoritas jasa keuangan, Syariah (ojk.go.id), diakses pada tanggal 13 Maret 2021 pukul 11:41,

${ }^{7}$ Ayu Dea Putri, Suarjaya Gede, Pengaruh profitabilitas terhadap nilai perusahaan dengan corporate social responsibility sebagai variabel mediasi pada perusahaan pertambangan, Junal Manajemen Unud, 2017
} 
Dinda Dwi W, Lu'Lu'Il Maknuun, Ahmad Mukhlisuddin : Pengaruh Fundamental Makro...

Dengan ini jika nilai perusahaan meningkat maka sentimen pada perusahaan tersebut akan di nilai baik ${ }^{8}$.

Nilai perusahaan pada bank syariah dapat dilihat pada rasio keuangan bank Syariah. Salah satu rasio keuangan syariah yang mengukutr nilai perusahaan adalah Return On Asset (ROA), karena rasio tersebut dapat mampu mengukur keberhasilan perusahaan atas aktivitas usahanya ${ }^{9}$. Serta dapat mengukur kemampuan bank Syariah dalam menghasilkan laba ${ }^{10}$.Sehingga apabila perusahaan dapat mencetak nilai laba yang baik maka usaha bank syariah dinilai berhasil, berikut ini data yang menunjukan Return On Asset (ROA)Bank syariah milik negara.

Gambar 1. Return On Asset Bank Syariah milik negara

\section{RETURN ON ASSET}

\begin{tabular}{|c|c|c|c|}
\hline & BRIS & BSM & BNIS \\
\hline 2020 & 0,81 & 1,65 & 1,33 \\
\hline 2019 & 0,31 & 1,69 & 1,82 \\
\hline 2018 & 0,43 & 0,88 & 1,42 \\
\hline 2017 & 0,51 & 0,59 & 1,31 \\
\hline 2016 & 0,95 & 0,59 & 1,44 \\
\hline
\end{tabular}

Sumber : Otoritas Jasa Keuangan

Data diatas menunjukan bahwa kemampuan bank Syariah milik negara dalam menghasilkan laba mengalami pasang surut. Pada Bank Syariah Mandiri mengalami kenaikan yang konsisten dalam menghasilkan laba dari tahun 2016-2020 dengan nilai 1.65\%. Sedangkan Bank Rakyat Indonesia Syariah (BRIS) mengalami penurunan dari tahun 2016-2020 pada nilai 0,81\%, sama halnya dengan Bank Negara Indonesia Syariah yang mengalami gejolak pasang surut dari tahun 2016-2020 dengan nilai 1,33\%. Penurunan ini dikarenakan suatu kondisi global yang terjadi pada saat ini yaitu pandemi Covid-19 yang menyerang seluruh sektor industri. Hal ini menjadi tantangan bagi perbankan dalam mempertahankan nilai laba pada kondisi saat ini.

Dalam menciptakan laba yang sesuai dengan capaian target, bank syariah memiliki tantangan dimana tantangan tersebut merupakan salah satu faktor eksternal yang dapat mempengaruhi capain target laba perusahaan, salah satu faktor eksternal ialah perubahan kondisi makro ekonomi yang diakibatkan lingkungan, kebijakan politik, sosial, issue, budaya, keamanan dan pendidikan atau hal lainya yang dapat

\footnotetext{
${ }^{8}$ Siringorunggo Renniwaty, Pratiwi Rahmni, Pengukuran tingkat profitabilitas perbankan syariah indonesia dengan menggunakan rasio camel periode 2012-2016, 2018.

${ }^{9}$ Siringorunggo Renniwaty, Pratiwi Rahmni, Pengukuran tingkat profitabilitas perbankan syariah indonesia dengan menggunakan rasio camel periode 2012-2016, 2018.

${ }^{10}$ Siringorunggo Renniwaty, Pratiwi Rahmni, Pengukuran tingkat profitabilitas perbankan syariah indonesia dengan menggunakan rasio camel periode 2012-2016, 2018.
} 
Dinda Dwi W, Lu'Lu'Il Maknuun, Ahmad Mukhlisuddin : Pengaruh Fundamental Makro...

menghambat aktivitas secara keseluruhan ${ }^{11}$. Makro ekonomi mampu mempengaruhi perubahan pasar dan keuangan negara melalui stabilitas harga, tenaga kerja, dan pencapaian keseimbangan, makro ekonomi dapat diukur melalui indikator-indikator produkdomestik bruto, inflasi, suku bunga dan perubahan nilai kurs indikator ${ }^{12}$. Berikut data dibawah ini sebagai berikut.

Gambar 2. Indikator Makro Ekonomi

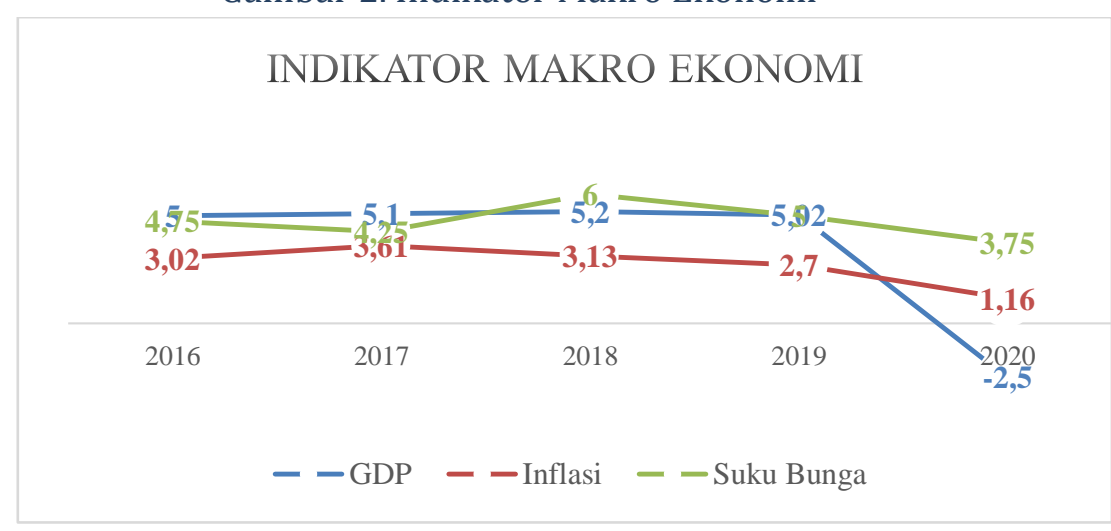

Sumber: Macrotrends

Data diatas menyatakan bahwa aktivitas ekonomi Indonesia mengalami pertumbuhan yang stagnan pada angka 5\% tahun 2016-2019, hingga mengalami keadaan minus pada tahun 2020 senilai -2,5\%. Dan terlihat bahwa inflasi Indonesia mengalami penurunan senilai $1.16 \%$, suku bunga pada 5 tahun terakhir mengalami penurunan yang rendah hingga mencapai $4,4 \%$, kebijakan suku bunga rendah ini dilakukan demi menstimulus aktivitas ekonomi pada sektor perbankan dalam menjalankan kegiatan usahanya ${ }^{13}$. Keadaan ekonomi yang mengalami penurunan ini diakibatkan adanya wabah Covid-19 yang menjadi wabah global hingga berdampak pada aktivitas ekonomi Indonesia.

Aktivitas ekonomi yang masih rentan ini akan berdampak pada kelangsungan hidup perusahaan bank syariah, dimana lingkungan yang mudah berubah-ubah akan berdampak negatif pada suatu perusahaan dalam menjalankan kegiatan usahanya ${ }^{14}$. Akutansi keuangan mengasumsikan konsep going concern pada setiap kegiatan aktivitas usaha, untuk menilai keberhasilan aktivitas usaha tersebut ${ }^{15}$. Going concern merupakan salah satu pendapat auditor yang memberikan sangsi atas kelangsungan usaha perusahaan dengan ungkapan opini wajar dengan pengecualian atau opini tidak wajar, pendapat wajar dengan pengecualian apabila perusahaan memiliki rencana untuk mengubah manajemen perusahaan, sebaliknya apabila perusahaan tidak memiliki rencana manajemen, maka audit akan menyatakan opini tidak wajar

\footnotetext{
${ }^{11}$ Sujianto Agus Eko, Sukarsono, Masrokan Prim, Studi Empiris Pada negara-negara Di ASEAN terpilih, (Jawa Timur: STAIN Tulungagung Press: 2012).

${ }^{12}$ Sujianto Agus Eko, Sukarsono, Masrokan Prim, Studi Empiris Pada negara-negara Di ASEAN terpilih, (Jawa Timur: STAIN Tulungagung Press: 2012).

${ }^{13}$ Kementrian Koordinator Bidang Perekonomian Republik Indonesia, "Outlook Perekonomian Indonesia, Pemulihan dan Transformasi Ekonomi Naional", 2020

${ }^{14}$ Mariyadi Agusm Wicaksono Bintoro Tri, Lingkungan Ekonomi, Binus University Business School,2018

${ }^{15}$ Harahap Sofyan S, Wiroso, Yusuf Muhamad, Akutansi Perbankan Syariah, LPFE Usakti, (Jakarta:cetakan keempat, 2010),
} 
Dinda Dwi W, Lu'Lu'Il Maknuun, Ahmad Mukhlisuddin : Pengaruh Fundamental Makro...

pendapat tersebut diperjelas dengan paragraf yang berkaitan atas kondisi yang berdampak pada kelangsungan usaha perusahaan ${ }^{16}$. hal ini diungkapkan pada laporan keuangan yang mana dijadikan sebagai informasi kepada investor atau pihak eksternal. Pengungkapan perusahaan melalui laporan keuangan merupakan informasi paling utama dalam kegiatan perusahaan untuk menampakkan value atau nilai perusahaan, melalui laporan keuangan perusahaan pihak stakeholder dapat berhatihati dalam membuat keputusan investasi ${ }^{17}$. Selain kelangsungan usaha, Investor juga mempertimbangkan kegiatan sosial yang dilakukan perusahaan dalam laporan keuangan sebagai pertangung jawaban sosial perusahaan ${ }^{18}$. Berdasarkan latar belakang ini, peneliti ingin meneliti penilain perusahaan pada bank syariah berprospektif pada aktivitas usaha bank Syariah yang sesuai dengan etika dan norma agama, meskipun terjadi kondisi ekonomi yang melemah.

\section{B.Landasan Teori}

\section{Manajemen Keuangan}

Manajemen keuangan berkaitan dengan kegiatan perencanaan, analisis dan pengendalian kegiatan keuangan. Kegiatan ini dilaksanakan oleh seorang manajer keuangan di perusahaan, keputusan yang harus ditentukan oleh seorang manajer keuangan akan berdampak pada kegiatan perusahaan. Kegiatan tersebut dapat dibagi menjadi dua kegiatan utama yaitu kegiatan menggunakan dan dan mencari pendanaan, kegiatan tersebut disebut sebagai fungsi manajemen keuangan.

a. Pemperoleh dana atau biasa disebut sebagai keputusan pendanaan, dalam memperoleh dana perusahaan tidak hanya mengandalkan modal, hutang atau keuntungan pada suatu bisnis yang dijalankan. Adapun kegiatan perolehan dana dalam meningkatkan aktiva perusahaan yaitu berasal dari pasar uang atau financial market, dimana pasar tersebut terjadinya demand and supply pada dana. Kegiatan perolehan dana dapat dilakukan dengan menjual saham kepemilikan perusahaan, penerbitan surat berharga, obligasi, dll.

b. Pengunaan dana atau biasa disebut sebagai keputusan investasi ialah keputusan manajemen keuangan dalam memanfaatkan modalnya dalam bentuk meningkatkan usaha atau kegiatan perusahaan. Pengunaan dana ini dapat digunakan sebagai operasional untuk menjalankan kegiatan sehari-hari perusahaan, pengunaan dana harus se-efesiens, efektif dan ekonomis agar tidak menimbulkan kerugian bagi perusahaan. Selain itu, pengunaan dana juga dapat di alokasikan pada kegiatan investati lainya untuk menambahkan keuntungan atau aktiva pada perusahaan.

c. Pembagian laba atau deviden, pembagian ini merupakan hak yang dimiliki oleh seorang yang memberikan dana tersebut pada perusahaan.

\footnotetext{
${ }^{16}$ Sinarwati Ni Kadek, Mengapa perusahaan menerima opini audit going concern, 2017

${ }^{17}$ Ibid

${ }^{18}$ Widowati Amerti Irvin,Surjawati, Oktoriza Linda Ayu,Dian Indriana TL. "Praktik islamic corporate social responsibility disclosure" (Studi Kasus Terhadap Perusahaan Yang Terdaftar Di Jakarta Islamic Indeks)", Jurnal dinamika sosial budaya, 2016
} 
Dinda Dwi W, Lu'Lu'Il Maknuun, Ahmad Mukhlisuddin : Pengaruh Fundamental Makro...

Ketiga keputusan tersebut menjadi fungsi manajemen keuangan untuk mengelola dan merancang keuangan dengan baik, karna ketiga keputusan tersebut menjadi rangkaian yang saling berkaitan dalam pengelolaan manajemen dana dimana keputusan investasi atau pengunaan dana akan terlihat pada sisi aktiva perusahaan yang akan mempengaruhi kekayaan perusahaan. Sedangkan keputusan pendanaan atau perolehan dana dan pembagian laba akan tercemin pada sisi pasiva perusahaan. Keputusan tersebut merupakan tugas seorang manjer keuangan agar memastikan kegiatan perusahaan dapat bertahan lama dan dapat menghasilkan keuntungan bagi perusahaan dan pemegang saham. Menciptakan manajemen keuangan yang efesien membutuhkan tujuan dan target yang tepat untuk digunakan sebagai standar dalam menilai efesiensi keputusan keuangan. Menurut Suad Husnan beberapa pertimbangan sosial pada tanggung jawab yaitu :

a. Pada dasarnya setiap tujuan keputusan keuangan ialah untuk memaksimumkan nilai perusahaan. Nilai perusahaan merupakan harga yang dapat dibayarkan investor, apabila perusahaan tersebut menerbitkan saham pada pasar modal.

b. Memaksimumkan laba perusahaan dengan juga memaksimumkan Earning Per Share (EPS) dengan memperhatikan nilai waktu, uang dan risiko

c. Keputusan dividen yang tepat.

\section{Akutansi Keuangan Syariah}

Akutansi keuangan Syariah adalah pengakuan, pengukuran dan pencatatan atas transaksi- transaksi serta pengungkapan atas kewajiban dan hak-hak pada laporan keuangan. Akutansi keuangan Syariah harus mengedepankan laporan yang bersifat jujur, adil dan terbuka atas posisi keuangan entitas (usaha), hasil-hasil operasional perusahaan, dan keterbukaan usaha atas sumber kegiatan yang berasal apa yang halal dan apa yang haram. Dengan itu dalam pembuatan laporan keuangan bank syariah harus berhati-hati dan sesuai dengan ketentuan- ketentuan yang sudah ditetapkan ${ }^{19}$.

Dalam menyusunan laporan keuangan syariah terdapat dua hal yang perlu di pahami dan perhatikan yaitu Kerangka Dasar Penyusunan dan Penyajian Laporan Keuangan Perbankan Syariah (KDPPLKPS) dan Penyajian Standar Akutansi (PSAK) 59. Kedua hal tersebut berisikan karateristik bank syariah, pengunaan kebutuhan informasi, tujuan akutansi keuangan, tujuan laporan keuangan, asumsi dasar, serta pengaturan atas pengukuran, pengakuan, pengungkapan dan penyajian terkait produkproduk perbankan syariah ${ }^{20}$. Adapun tujuan dalam pembentukan akutansi keuangan bank syariah ialah sebagai berikut ${ }^{21}$ :

\footnotetext{
${ }^{19}$ Harahap Sofyan S, Wiroso, Yusuf Muhamad, Akutansi Perbankan Syariah, LPFE Usakti, (Jakarta:cetakan keempat, 2010),

${ }^{20}$ Harahap Sofyan S, Wiroso, Yusuf Muhamad, Akutansi Perbankan Syariah, LPFE Usakti, (Jakarta:cetakan keempat, 2010),

${ }^{21}$ Harahap Sofyan S, Wiroso, Yusuf Muhamad, Akutansi Perbankan Syariah, LPFE Usakti, (Jakarta:cetakan keempat, 2010),
} 
Dinda Dwi W, Lu'Lu'Il Maknuun, Ahmad Mukhlisuddin : Pengaruh Fundamental Makro...

a. Menentukan hak dan kewajiban pihak terkait, termasuk transakasi yang belum selesai atau kegaitan ekonomi lainya yang masih dalam proses, sesuai dengan prinsip Syariah yang berlandasskan pada konsep kejujuran, keadilan, kebijakan, dan kepatuhan terhadap nilai-nilai bisnis Syariah.

b. Menyajikan informasi keuangan yang berguna bagi para pengguna laporan keuangan dalam mempertimbangkan keputusan

c. Meningkatkan kepatuhan pada prinsip Syariah dalam transaksi dan kegiatan usaha.

Laporan keuangan yang berguna merupakan informasi keuangan yang dapat dipahami, relevan, mudah, dan dapat ditinjau dengan tahun sebelumnya. Penyusunana laporan keuangan pencatatan laporan keuangan bukan hanya dengan angka dan posisi akun, melainkan sarana komunikasi yang dapat membantu para pengguna informan dalam menilai perusahaan bank Syariah tersebut.

\section{Laporan Keuangan Bank Syariah}

Karateristik bank Syariah yang berbeda dengan konsep akutasni konvensial, membawa konsekuensi pelaporan yang berbeda. Sehingga laporan keuangan syariah meliputi 22 :

a. Laporan keuangan yang mencerminkan kegiatan bank syariah sebagai investor beserta hak dan kewajibanya, dilaporkan dalam :

i.Laporan posisi keuangan

ii.Laporan laba-rugi

iii.Laporan arus kas

iv.Laporan perubahan ekuitas

b. Laporan keuangan yang menampakan perubahan terkait investasi terikat yang dikelola oleh bank Syariah dilaporkan dalam laporan perubahan dana investasi terikat

c. Laporan keuangan yang menampakan peran bank Syariah dalam menjalankan fungsi sosialnya dilapokan secara terpisah yaitu :

i. Laporan sumber dan pengunaan dana zakat

ii. Laporan sumber dan pengunaan dana kebajikan

\section{Makro Ekonomi}

Robert S. Pindyck dan Daniel L. Rubinfield menyatakan bahwa makro ekonomi ialah sebuah ilmu yang menangani variable agregat ekonomi seperti, tingkat dan ratarata pertumbukan produk nasional, suku bunga, inflasi dasn tingkat penganguran. Adapun faktor- faktor yang menimbulkan fundamental makro ekonomi sebagai berikut

a. Faktor yang menimbulkan Fundamental Makro Ekonomi

1) Produk Domestik Bruto

\footnotetext{
${ }^{22}$ Wiroso, "Pengantar Akutansi Syariah", IAI, Akutansi Lembaga Keuangan Syariah, 2013.
} 
Dinda Dwi W, Lu'Lu'll Maknuun, Ahmad Mukhlisuddin : Pengaruh Fundamental Makro...

Produk Domestik Bruto (PDB) merupakan mengambarkan pendapatan nasional melalui tingkat produksi negara atas barang dan jasa yang telah dicapai dalam dan pendapatan total dari setiap penduduk satu periode atau satu tahun ${ }^{23}$. Poduk domestik bruto digunakan untuk menilai perstasi pertumbuhan ekonomi, menentukan tingkat kemakmuran masyarakat dan perkembanganya ${ }^{24}$. Produk domestik bruto bersumber dari penduduk lokal negara tersebut, yang dimaksud ialah output yang dihasilkan atau diproduksi di dalam negeri tersebut dan ditambah produksi yang dihasilkan warga asing. Poduk domestik bruto digunakan untuk menilai perstasi pertumbuhan ekonomi, menentukan tingkat kemakmuran masyarakat dan perkembangan suatu negara.

2) Inflasi

Inflasi ialah suatu keadaan dimana meningkatnya rata-rata harga kebutuhan msayarakat secara terus-menerus dan kenaikan harga tersebut mempengaruhi kenaikan harga barang lainya ${ }^{25}$. Menurut samuelson menyatakan bahwa inflasi ialah suatu keadaan dimana terjadinya kenaikan harga umum yang mengindkasikan keadaaan melemahnya daya beli pada masyarakat yang mengakibatkan menurunya nilai rill (instristic) mata uang suatu negara.

3) Suku bunga

Suku bunga merupakan kebijakan Bank Indonesia yang mencerminkan kebijakan moneter suku bunga dapat mengatur pergerakan aktivitas ekonomi. karena suku bunga digunakan dalam suatu pembayaran dan pinjaman yang dibentuk dalam presentasi dari pokok utang yang dibayarkan sebagai return atau imbal dalam periode tertentu. Dengan itu suku bunga merupakan sistem rujukan bagi pergerakan operasional perbankan dan juga sistem perekonomian. Suku bunga dapat berubah sesuai dengan kondisi yang terjadi pada suatu negara. Perubahan kebijakan pada suku bunga dapat mempengaruhi keputusan investasi bagi investor pada perusahaan. Hal ini akan berkaitan dengan beban bunga dan juga pengurangan pada laba yang akan mengalami penurunan, dan akan menimbulkan sentimen yang negatif pada perusahaan emiten tersebut ${ }^{26}$.

4) Nilai Tukar

Nilai tukar menurut Mankiw adalah pertukaran harga matauang antar dua negara yang digunakan oleh penduduk negara tersebut dengan tujuan untuk melakukan perdagangan antara satu sama lain ${ }^{27}$. Dapat disimpulkan bahwa nilai tukar adalah harga pada nilai mata uang suatu negara terhadap negara lain, yang digunakan sebagai alat transaksi tukar menukar dalam perdagangan antara negara, yang mana nilai tukar tersebut ditentukan oleh penawaran dan

\footnotetext{
${ }^{23}$ N.G. Mankiw, Pengantar Ekonomi Makro, Edisi 3, terjemahan, Jakarta:Salemba Empat 2006.

${ }^{24}$ Sujianto Agus Eko, Sukarsono, Masrokan Prim, Studi empiris pada negara-negara di asean terpilih, (Jawa Timur: Stain Tulungagung Press, 2012).

${ }^{25}$ Bank Indonesia, www.bi.go.id, diakses pada tanggal 26 Maret 2021

${ }^{26}$ Amalia, Resya Rizkiy. Pengaruh Faktor-Faktor Fundamental dan Variabel Makro Ekonomi Terhadap Return Saham (Studi Empiris pada perusahaan consumer goods sub sector Food and Beverages yang tedaftar di BEI 2014-206), Uniersitas Islam Indonesia, 2018

${ }^{27}$ N.G. Mankiw, Pengantar Ekonomi Makro, Edisi 3, terjemahan, Jakarta:Salemba Empat 2006.
} 
Dinda Dwi W, Lu'Lu'Il Maknuun, Ahmad Mukhlisuddin : Pengaruh Fundamental Makro...

permintaan dari kedua mata uang. Nilai mata uang suatu negara dapat mengalami perubahan karena kondisi ekonomi, sosial politik ${ }^{28}$. Perubahan tersebut dapat mengalami apresiasi ataupun depresiasi, kondisi apresiasi terjadi apabila mata uang domestic terhadap mata uang luar mengalami kenaikan, sedangkan kondisi depresiasi ketika mata uang domestik mengalami penurunan terhadap mata uang asing 29 .

\section{Islamic Coorporate Social Responsibility}

Islamic corporate social responsibility merupakan pengungkapan pertangung jawaban sosial perusahaan kepada masyarakat dan lingkungan dalam bentuk imbal balik perusahaan yang telah mengunakan SDM dan SDA pada masyarakat dan lingkungan dengan tujuan untuk menacapo ekonomi islam yang sejahtera, kesetaraan, distribusi pendapatan yang adil dan kebebasan indivisual dalam konteks kesejahteraan sosial ${ }^{30}$. Konsep ICSR yang dikemas sesuai dengan prinsip Syariah islam menyempurnakan niat perusahaan untuk memberikan perhatian khusus terhadap program CSR ${ }^{31}$. Awal mula ICSR merupakan hasil induk dari konep CSR yang telah di impelmentasikan oleh seluruh negara khusunya negara-negara barat pada tahun 1950$\mathrm{an}^{32}$.

Pengungkapan dan pelaporan tentang ICSR perusahaa merupakan kewajiban bagi perseroan, undang undang No 40 tahun 2007 pasal 74 menjelaskan bahwa perusahaan yang menjalankan kegiatan bisnisnya pada bidang atau berkaitan dengan pengelolaan sumber daya alam, wajib melakukan tanggung jawab sosial dan lingkungan, apabila terdapat unsur kepalsuan pelaksanaan maka akan diberikan sanksi seuai dengan ketentuan perundang-undangan. Dalam kerangka Islamic corporate social responsibility yang disusun dan ditetapkan oleh Accounting and Auditing Standard for Islamic Financial Institutions (AAOFII) yang dikembangkan oleh para peneliti. Dalam penelitian ini, penulis mengunakan indeks ICSR yang dirancang oleh Hanifia dengan 6 item pengungkapan yang dapat dijadikan acuan dalam pengungkapanya secara keseluruhan kategori tersebut yakni: keuangan dan investasi, produk dan jasa, karyawan,sosial, lingkungan, tata kelola perusahaan.

Dalam penelitian Putri dan Budiyanto menyatakan bahwa manfaat pengungkapan ICSR bagi perusahaan ialah (a) mempertahankan dan mendongkrak reputasi dan citra perusahaan, (b) mendapatkan izin usaha dalam menjalankan kegiatan sosial, (c) mereduksi risiko bisnis perusahaan, (d) memperluas sumber daya operasional usaha, (e) memperluas peluang pasar, (f) meningkatkan hubungan dengan stakeholders, (g) meningkatkan semangat dan kinerja karyawan, (h) mendapatkan penghargaan dari pemerintah yang akan meningkatkan citra perusahaan

\footnotetext{
${ }^{28}$ N.G. Mankiw, Pengantar Ekonomi Makro, Edisi 3, terjemahan, Jakarta:Salemba Empat 2006.

${ }^{29}$ N.G. Mankiw, Pengantar Ekonomi Makro, Edisi 3, terjemahan, Jakarta:Salemba Empat 2006.

${ }^{30}$ Wahyuddin, Islamic Coorporate Social Resposibilty (ICSR); Kajian Teoritis,

${ }^{31}$ Wahyuddin, Islamic Coorporate Social Resposibilty (ICSR); Kajian Teoritis,

${ }^{32}$ Siti Norasmarina ismail 2009
} 
Dinda Dwi W, Lu'Lu'Il Maknuun, Ahmad Mukhlisuddin : Pengaruh Fundamental Makro...

\section{Audit Opinion Going Concern}

Menurut Peryataan Standar Auditing (PSA) No 30 audit opinion going concern adalah kelangsungan hidup suatu badan usaha atas kegiatan aktivitas usahanya 33 . Menurut Ikatan Akuntan Indonesia (IAI) going concern adalah kesangsian atas kemampuan satuan usaha dalam mempertahankan aktivitas usahanya selama periode waktu yang pantas, yaitu lebih dari satu tahun sejak tanggal laporan keuangan auditan $^{34}$. Adapaun standar audit 570.1 paragraf 2 memberikan pengertian mengenai opini audit going concern ${ }^{35}$.

"Berdasarkan asumsi kelangsungan usaha dan suatu entitas dipandang dalam bisnis untuk masa depan yang dapat diprediksi“ .

Opini audit going concern atau keberlangsungan hidup perusahaan yang dinyatakan oleh auditor dimana keadaan apakah perusahaan dapat mempertahankan kelangsungan hidupnya secara jangka panjang. Dalam hal penilaian ini auditee mendapati indikasi resiko auditee tidak dapat bertahan lama dalam bisnis, penilaian auditee dilihat dari sudut pandang yang melibatkan beberapa tahapan analisis melalui laporan keuangan dengan mempertimbangkan hasil dari kondisi ekonomi yang mempengaruhi perusahaan, kegsiatan operasional, kemampuan membayar hutang dalam jangka pendek dan panjang serta kebutuhan likuiditas dimasa yang akan datang 36. Adanya pendapat mengenai going concern dianggap akan mampu mempertahankan kegiatan usahanya dalam jangka waktu panjang, dan tidak akan terlikuidasi.

Auditor melaksanakan fungsi monitoring atas pekerjaan manajer melalui laporan keuangaan, sehingga auditor melakukan tahapan audit pada kewajaran laporan keuangan yang terdiri dari neraca, laporan laba rugi, laporan perubahan modal dan laporan arus kas termasuk catatan atas laporan keuangan yang kemudian diberikan kesimpulan penilaian dalam bentuk opini audit ${ }^{37}$. Bentuk penilaian opini auditor menggunakan laporan keuangan dengan mempertimbangkan keputusan ekonomi, dengan begitu informasi audit laporan keuangan perusahaan sangat penting bagi pengguna laporan keuangan ${ }^{38}$. salah satu opini audit ialah opini going concern yang dinyatakan secara jelas oleh auditor dengan pendapat wajar dengan pengecualian atau tidak wajar, apabila terdapat keraguan atas kemampuan perusahaan untuk melanjutkan usahanya seperti masalah kesulitan keuangan, kerugian usaha yang besar dan berulang, ketidamampuan perusahaan dalam melaksanakan kewajibanya, terjadinya bencana yang tidak diasuransikan, perkara pengadilan dll.

\footnotetext{
${ }^{33}$ Standar Audit SA No 30, Tanggung Jawab Auditor Terhadap Opini Audit Going Concern - Accounting (binus.ac.id), diakses pada tanggal 4 April 2021

${ }^{34}$ Ikatan Akutansi Indonesia, Ikatan Akuntan Indonesia (IAI) (iaiglobal.or.id) diakses pada tanggal 4 April, 2021

${ }^{35}$ Standar Audit SA 570, 2013

${ }^{36}$ Rachman Anita, Afifudin, Mawardi M Cholid, Pengaruh likuiditas dan pertumbuhan perusaahaan terhadap opini audit going concern, (Malang, FEB Universitas Islam Malang,2020)

${ }^{37}$ Mulyadi, Mannan Salam, Modul Auditing, (Jakarta, Universitas Terbuka: 2008)

${ }^{38}$ Rachman Anita, Afifudin, Mawardi M Cholid, Pengaruh likuiditas dan pertumbuhan perusaahaan terhadap opini audit going concern, (Malang, FEB Universitas Islam Malang,2020)
} 
Dinda Dwi W, Lu'Lu'Il Maknuun, Ahmad Mukhlisuddin : Pengaruh Fundamental Makro...

\section{Nilai perusahaan}

Nilai perusahaan ialah capaian perusahaan dalam meningkatkan nilai berupa angka, citra atau yang biasanya diukur dengan harga saham perusahaan tersebut. Yang mana semakin tinggi harga saham perusahaan tersebut maka semakin meningkat juga citra perusahaan, dan sebaliknya apabila harga saham perusahaan turun maka akan menurun juga citra perusahaan. Oleh karena itu dalam teori keuangan pasar modal harga saham disebut sebagai konsep nilai perusahaan ${ }^{39}$. Nilai perusahaan dapat memberikan keuntungan pata pemegang saham secara maksimal apabila harga saham perusahaan meningkat, semakin tinggi harga saham maka semakin tinggi tingkat pengembalian para pemegang saham ${ }^{40}$.

Menurut harmono berikut indikator yang mempengaruhi nilai perusahaan dapat diukur dengan mengunakan ${ }^{41}$ :

a. $\quad$ Price Book Value (PBV)

Price Book Value atau nilai harga buku merupakan salah satu indikator yang menjadi pertimbangan investor dalam mengambil keputusan investasi. Price book value dapat diukur apabila perusahaan tersebut sudah memperjual belikan sahamnya di pasar modal dengan nilai buku saham. Berikut perhitungan Price book value:

b. $\quad$ Price Earning Ratio (PER)

$$
\mathrm{PBV}=\frac{\text { Harga saham perlembar }}{\text { Nilai buku saham }}
$$

Price Earning Ratio adalah harga perlembar saham yang di dasari oleh laba perusahaan dalam laporan keuangan, indikato PER menjadi bentuk standar pelaporan keuangan bagi perusahaan publik. Karena dapat mengukur seberapa banyak perusahaan dalam menghasilkan laba, Berikut perhitungan PER:

\section{c. $\quad$ EPS (Earning Per Share)}

$$
\text { PER }=\frac{\text { Harga saham }}{\text { Laba per lembar saham }}
$$

Earning Per Share ialah pendapatan per lembar saham merupakan bentuk pemberian atau pembagian keuntungan perusahaan kepada investor dari setiap lembar saham yang dimiliki oleh investor. Berikut perhitungan Earning Per Share:

$$
\text { EPS }=\frac{\text { Laba setelah pajak }}{\text { jumlah lembar saham beredar }}
$$

\section{Metodologi Penelitan}

Racangan penelitian ini iala sebuah rancangan yang merujuk bagaimana penelitian akan digunaan dan dilakukan untuk mendapatkan jawaban terhadap rumusan masalah yang ditentutkan oleh penleliti. Dalam pelaksanaan penelitian ini menggunakan metode Teknik analisis data kuantitatif yang bertujuan menguji hipotesis antar variabel yang

\footnotetext{
${ }^{39}$ Harmono, Manajemen Keuangan berbasis balanced, (Jakarta:Pt Bumi Angkasa Raya, 2015)

${ }^{40}$ Ibid

${ }^{41}$ Harmono, Manajemen Keuangan berbasis balanced, (Jakarta:Pt Bumi Angkasa Raya, 2015)
} 
Dinda Dwi W, Lu'Lu'Il Maknuun, Ahmad Mukhlisuddin : Pengaruh Fundamental Makro...

dihubungkan dan menjelaskan pengaruh hubungan kausal antar variabel-variabel melalui pengujian hipotesis yang didukung dengan fakta atau data empiris ${ }^{42}$. Ruang lingkup penelitian ini secara khusus pada ilmu investasi dan keuangan, yang dititikberatkan pada variabel nilai perusahaan, terutama pengaruh antar variabel bebas makro ekonomi, Islamic corporate social responsibility yang ditengahi dengan variabel intervening audit opinion going concern terhadap nilai perusahaan di sektor perbankan milik BUMN. Pada penelitian ini, populasi yang akan diteliti ialah Bank Umum Syariah Milik Negara yang berplat merah yang terdiri : Bank Syariah Mandiri, Bank Negara Indonesia Syariah, dan Bank Republik Syariah Indonesia tahun 2015-2020.

Table 1.Sampel Penelitian

\begin{tabular}{|c|c|c|c|}
\hline No & Nama Bank & Periode & Tinjauan \\
\hline 1 & Bank Syariah Mandiri (BSM) & $2016-2020$ & $\begin{array}{c}\text { Laporan } \\
\text { keuangan }\end{array}$ \\
\hline 2 & $\begin{array}{c}\text { Bank Negara Indonesia Syariah } \\
\text { (BNIS) }\end{array}$ & $2016-2020$ & $\begin{array}{c}\text { Laporan } \\
\text { keuangan }\end{array}$ \\
\hline 3 & $\begin{array}{c}\text { Bank Rakyat Syariah Indonesia } \\
\text { (BRIS) }\end{array}$ & $2016-2020$ & $\begin{array}{c}\text { Laporan } \\
\text { keuangan }\end{array}$ \\
\hline 4 & $\begin{array}{c}\text { Bank Tabungan Pensiun } \\
\text { Nasional Syariah (BTPNS) }\end{array}$ & $2016-2020$ & $\begin{array}{c}\text { Laporan } \\
\text { keuangan }\end{array}$ \\
\hline
\end{tabular}

Sumber : hasil olah peneliti

Jenis dan sumber data yang digunakan pada penelitian ini ialah data sekunder yang bersumber Library Research, pengetahuan yang diolah melalui angka-angka dan mengunakan analisis statistik ${ }^{43}$. Pengunaan data dalam penelitian ini ialah data sekunder, data sekunder tersebut dialmbil dalam bentuk laporan keuangan yang berdasarkan data runtut waktu (time series) dan individual (cross section) periode 2015-2020.

Adapun dalam penelitian ini memerlukan beberapa data atau indikator sebagai penunjang variabel untuk menjelaskan pengaruh variable Fundamental Macro, Islamic Coorporate Social Responsibility terhadap nilai perusahaan melalui Audit Opinion Going Concern. Dengan demikian peneliti sajikan dalam bentuk tabel berikut:

Tabel 2. Variabel, symbol dan Indikator penelitian

\begin{tabular}{|c|c|c|c|}
\hline \multicolumn{2}{|c|}{ Variabel } & $\begin{array}{c}\text { Angka- } \\
\text { angka }\end{array}$ & Indikator \\
\hline \multirow{4}{*}{$\begin{array}{c}\text { Independent } \\
\text { Varibels }\end{array}$} & $\begin{array}{c}\text { Fundamental } \\
\text { Macro (X1) }\end{array}$ & $\mathbf{X 1 . 1}$ & Inflasi \\
\cline { 2 - 4 } & X1.2 & Suku Bunga \\
\cline { 2 - 4 } & $\begin{array}{c}\text { X1.3 } \\
\text { Islamic Corporate } \\
\text { Social }\end{array}$ & $\mathbf{X 2 . 1}$ & Poduk Domestik Bruto \\
\cline { 2 - 4 } & $\mathbf{X 2 . 1}$ & Produangan Dan Investasi \\
\hline
\end{tabular}

\footnotetext{
${ }^{42}$ Edi Purwanto, Metode Penelitian Kuantitatif (Semarang: Fakultas Ilmu Pendidikan Universitas Negeri Semarang, 2013), 68

${ }^{43}$ Sugiyono, Metode penelitian Kuantitatif, Kualitatif, dan R\&D, Bandung, Alfabeta, 2008.
} 
Dinda Dwi W, Lu'Lu'Il Maknuun, Ahmad Mukhlisuddin : Pengaruh Fundamental Makro...

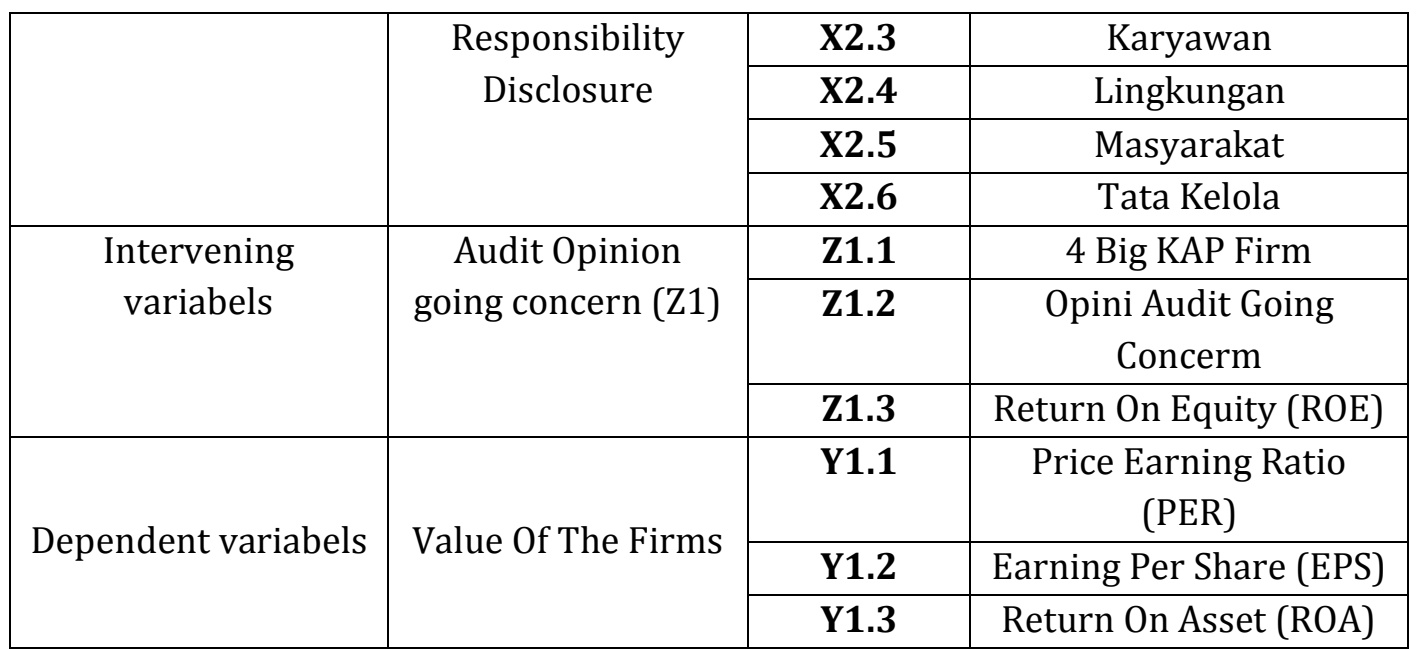

Sumber : hasil olah peneliti

Gambar 3. Kerangka Konseptual

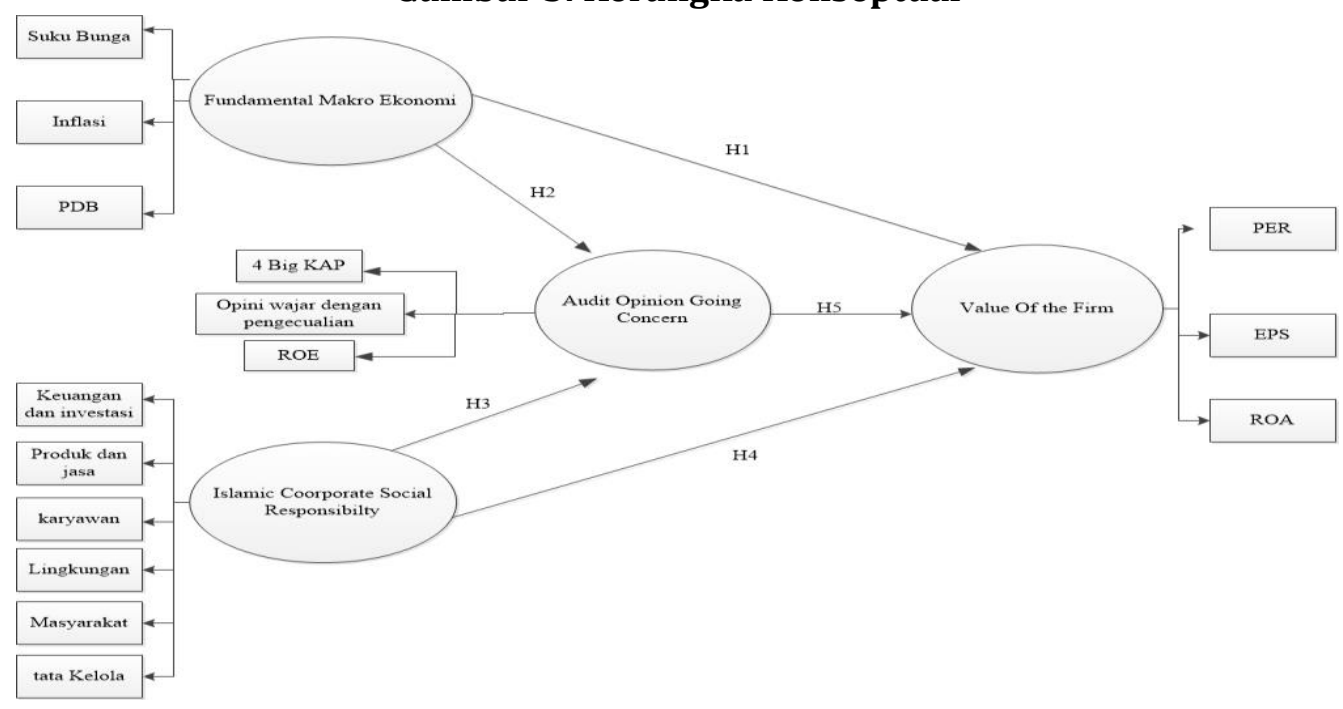

Sumber : hasil olah peneliti

Penelitian ini menggunakan alat PLS, peneliti dapat memasukan variabel-variabel yang dapat diukur namun tidak dapat diamati dengan pengunaan persamaan struktutal dan diukur dengan indikator-indikator variabel pendukung. Peneliti memilih PLS karna alat ini menggunakan metode bootstrapping atau pengandaan secara acak dengan asumsi normalitas dan juga tidak mensyaratkan jumlah minimum sampel ${ }^{44}$. pengujian dilakukan dengan dua model yaitu 1) model pengukuran (Outer Model), 2) Struktural model (Inner Model). Adapun pengukuran Outer Model digambarkan dengan menguji validitas konstruk dan reliabilitas instrument, pengujian validitas dan reliabilitas didahulukan sembelum pendistribusian instrument, untuk menguji kevalidan dan reliabel dalam pengumpulan data. Adapun pengujian validitas ialah : (1) uji validitas konstruk, yang terdiri dari convergent validity, discriminant validity. Kedua pengujian tersebut memelikin standar pengukuran yaitu hasil loading faktor harus diatas lebih dari 0,5. (2) reliabilitas instrument terdiri dari cronbachs alpha dan composite reliability, pengukuran item dapat dkatakan reliabel apabila nilai koefisien lebih dari

\footnotetext{
${ }^{44}$ Anuraga Ganga, Edy Sulistiyawan, Munadhiroh Siti, “structural equation modeling - partial least square untuk pemodelan indeks pembangunan kesehatan masyarakat (ipkm) di jawa timur, Universitas Airlangga, 2017
} 
Dinda Dwi W, Lu'Lu'Il Maknuun, Ahmad Mukhlisuddin : Pengaruh Fundamental Makro...

0,7. Dan pengujian model structural (Inner Model) ialah pengambaran hubungan kolerasi antara variabel laten yang terbentuk berdasarkan teori-teori. Dengan pengujian nilai R-square pada konstruk dan nilai t-statstik pada pengujian kofesian jalur

\section{Hasil Dan Pembahasan}

Penelitian ini mengunakan standar loading faktor berdasarkan hubungan antara variabel dengan nilai konstrak dan skala ukuran yang dinilai cukup yaitu 0,5. Adapun hasil test ditunjukan pada gambar dibawah ini :

Gambar 4. Hasil model pengukuran (Inner Model)

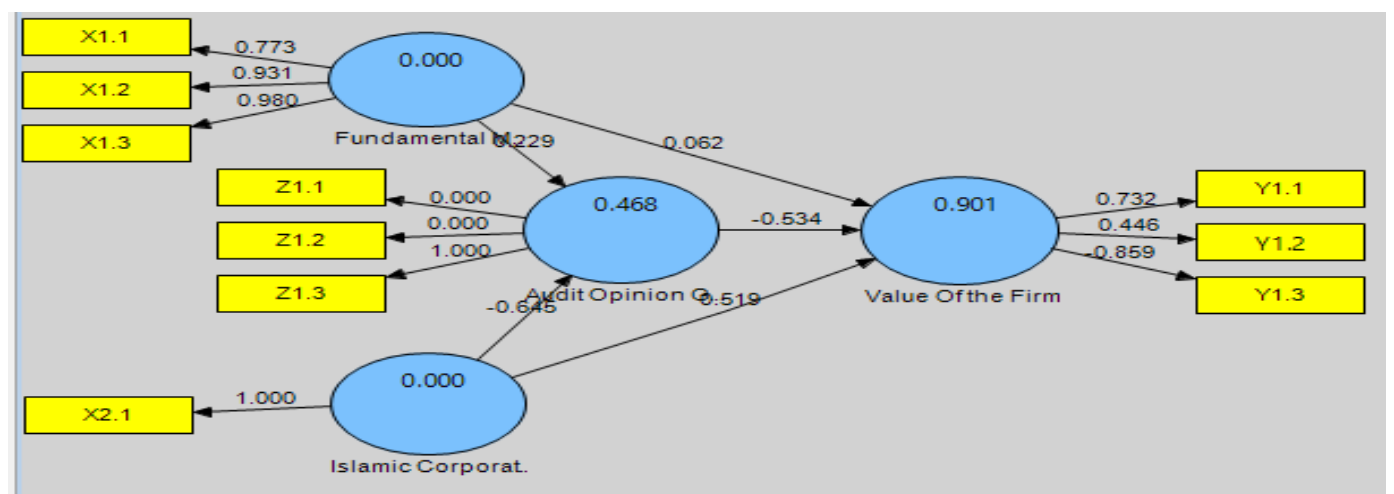

Sumber : hasil olah peneliti

Ketentuan hubungan antara variabel memiliki standar statistic yaitu tingkat signifikansi level pada nilai original sampel dibawah 0,5 dan t-tabel diatas 1,96. Dengan standar nilai tersebut maka hipotesis dapat diterima. Adapun hasil hipotesis menunjukan hasil dibawah ini:

Tabel 3. Hasil dari PLS Analysis

\begin{tabular}{|c|c|c|c|c|c|c|}
\hline $\begin{array}{c}\text { Hubungan } \\
\text { Konstruk }\end{array}$ & $\begin{array}{c}\text { Sampel } \\
\text { Asli (0) }\end{array}$ & $\begin{array}{c}\text { Rata-rata } \\
\text { Sampel } \\
\text { (M) }\end{array}$ & $\begin{array}{c}\text { Standar } \\
\text { Deviasi } \\
\text { (STDEV) }\end{array}$ & $\begin{array}{c}\text { T Statistik } \\
\text { (I } \\
\text { O/STDEV } \\
\text { I) }\end{array}$ & P Values & Keterangan \\
\hline $\begin{array}{c}\text { Fundamental } \\
\text { Makro-> Nilai } \\
\text { Perusahaan }\end{array}$ & 0.014 & 0.013 & 0.104 & 5.137 & 0.000 & Signifikan \\
\hline $\begin{array}{c}\text { Fundamental } \\
\text { Makro-> } \\
\text { Audit Opinion } \\
\text { Going } \\
\text { Concern }\end{array}$ & 0.2329 & 0.2294 & 0.0629 & 3.6382 & 0.000 & Signifikan \\
\hline $\begin{array}{c}\text { Islamic } \\
\text { Coorporate } \\
\text { Social } \\
\text { Responsibility } \\
\text {-> Audit }\end{array}$ & -0.683 & -0.008 & 0.664 & 1.027 & 0.645 & Signifikan \\
\hline
\end{tabular}


Dinda Dwi W, Lu'Lu'Il Maknuun, Ahmad Mukhlisuddin : Pengaruh Fundamental Makro...

\begin{tabular}{|c|c|c|c|c|c|c|}
$\begin{array}{c}\text { Opinion Going } \\
\text { Concern }\end{array}$ & & & & & \\
\hline $\begin{array}{c}\text { Islamic } \\
\text { Coorporate } \\
\text { Social } \\
\text { Responsibility } \\
->\text { Nilai } \\
\text { Perusahaan }\end{array}$ & -0.4192 & -0.008 & 0.664 & 9.4887 & 0.000 & Signifikan \\
\hline $\begin{array}{c}\text { Audit Opinion } \\
\text { Going } \\
\text { Concern -> } \\
\text { Nilai } \\
\text { Perusahaan }\end{array}$ & 0.0343 & 0.55 & 0.384 & 8.8162 & 0.000 & Signifikan \\
\hline
\end{tabular}

Sumber : hasil olah peneliti

Uji hubungan antara konstruk diatas menunjukan bahwa hubungan pada makro terhadap nilai perusahaan dinyatakan positif signifikan dengan nilai T-hitung sebesar 5.137 (T-statistik > 1,96). Pada hubungan makro terhadap AOGC mendapati nilai Tstatistik sebesar 3.6382 yang menunjukan bahwa hubungan tersebut positif signifikan. Pada hubungan ICSR terhadap nilai perusahaan menunjukan nila T-statistik sebesar 9. 4887 yang menyatakan bahwa memiliki hubungan signifikan namun pada nilai original sampel menyatakan nilai negatif, dapat disimpulkan bahwa hubungan tersebut ialah berpengaruh negatif. Dan hubungan antara AOGC terhadap nilai perusahaan ialah sebesar 8.8162 yang menunjukan bahwa terdapat pengaruh positif signifikan, sedangkan pada hubungan ICSR terhadap AOGC memiliki nilai sebesar 1.027 (T-hitung $<1,96$ ) yang menunjukan bahwa pengaruh tidak signifikan.

Dari hasil data diatas menunjukan beberapa faktor mengenai hubungan antara variabel yang menunjukan hasil signifikan dan tidak signifikan. Adapun jawaban atas hipotesa tersebut sebagai berikut :

1. H1: pengaruh Fundamental Makro terhadap Value Of the Firm.

Berdasarkan hasil analisis data pada hubungan variabel Fundamental Makro terhadap nilai perusahaan menyatakan terdapat pengaruh positif signifikan. Hal tersebut menunjukan diterimanya $\mathrm{H}_{1}$ yang menyatakan bahwa fundamental makro berpengaruh signifikan terhadap nilai perusahaan. Hal ini menunjukan bahwa keadaan makro yang terjadi di Indonesia memiliki pengaruh yang besar terhadap nilai perusahaan, hal ini ditandai terjadinya penurunan pada PER,EPS dan ROA perusahaan disaat nilai pertumbuhan perekonomian Indonesia mengalami minus yang diakibatkan oleh penyebaran virus covid-19, dimana keadaan ini ditetapkan menjadi wabah atau pandemi global yang menyerang sebagian negara dan berdampak pada kegiatan sektor ekonomi, pendidikan, Industri dll. namun penurunan tersebut tidak memberikan dampak yang negative pada perbankan dimana, industri perbankan menjadi pendukung perekonomian Indonesia disaat terjadinya penurunan Product Domestic Bruto hingga mencapai titik minus. 
Dinda Dwi W, Lu'Lu'Il Maknuun, Ahmad Mukhlisuddin : Pengaruh Fundamental Makro...

Gambar 5. IDX BUMN 20

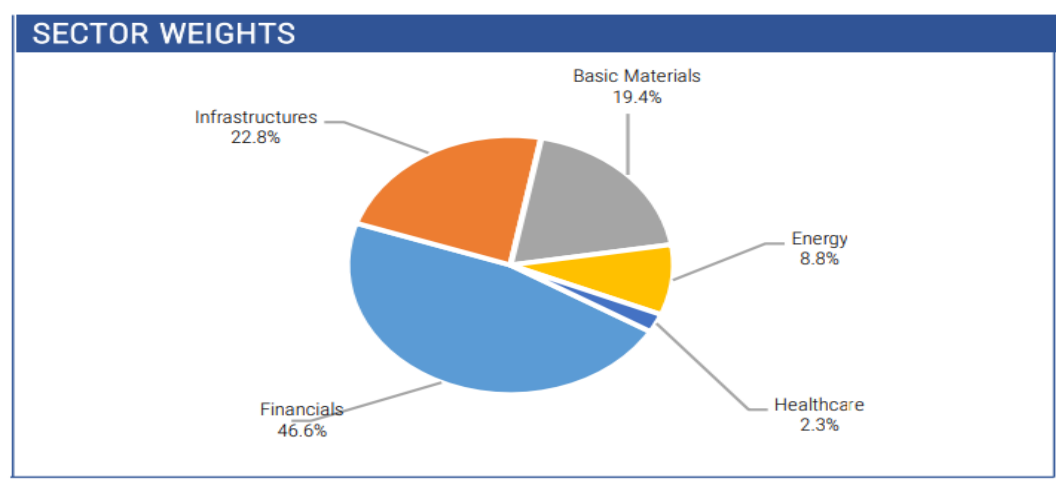

\section{Sumber Indonesia Stock Exchange}

Dari data diatas ditunjukan bahwa 46.6\% penunjang IHSG didukung oleh sektor keuangan yaitu perbankan Hal ini ditandai dengan gejolak pasar modal yaitu IHSG, dimana perbankan milik negara menjadi pendukung paling besar dalam menopang pergerakan pasar modal di Indonesia ${ }^{45}$. dengan itu meskipun terjadi pandemi, kekuatan fundamental nilai perbankan akan tetap baik dan stabil. hal ini akan menjadikan pertimbangan bagi investor dalam memutuskan kebijakan investasinya pada perbankan khususnya perbankan syariah.

Hal ini membuktikan bahwa fundamental perbankan memiliki stabilitas keuangan yang baik dan mampu bertahan meskipun kondisi ekonomi Indonesia menurun pada tahun 2021. Hasil penelitian ini berbeda dengan penelitian yang dilakukan oleh Ahmad fatoni karim A, Hermanto, I nym, Nugraha Ardana $p$ yang menyatakan bahwa fundamental makro tidak berpengaruh signifikan terhadap nilai perusahaan ${ }^{46}$. namun sejalan dengan penelitian yang dilakukan oleh Hwihanus,H., Ratnawati, T., \& Yuhertiana, I yang menyatakan bahwa terdapat hubungan positif signifikan pada fundamental makro terhadap nilai perusahaan.

Dengan itu dapat disimpulkan bahwa keadaaan ekonomi yang terjadi di Indonesia merupakan salah satu faktor eksternal yang akan mempengaruhi persepsi dan keputusan investor dalam memutuskan kebijakan investasinya.

2. H2: pengaruh Fundamental Makro terhadap Audit Opinion Going Concern.

Berdasarkan hasil analisis data tabel 4.12 pada hubungan variabel Fundamental Makro terhadap Audit Opinion Going Concern menyatakan terdapat positif signifikan. Hal tersebut menunjukan diterimanya $\mathrm{H}_{2}$ yang menyatakan berpengaruh signifikan hubungan fundamental makro terhadap Audit Opinion Going Concern.

Dengan hasil ini menunjukan bahwa keadaan makroekonomi mempengaruhi auditor serta menjadikan pertimbanganya dalam memberikan opini atas kelangsungan usaha pada perusahaan. Dalam kasus ini auditor memberikan opini dengan menyesuaikan keadaan dan kondisi yang tidak bisa ditangani oleh manusia seperti

\footnotetext{
${ }^{45}$ www.idx.co.id diakses pada tanggal 14 Juli 2021 jam 7:59 PM

46 Dwipartha Ni Made With a, "Pengaruh faktor ekonomi makro dan kinerja keuangan terhadap nilai perusahaan manufaktur di bursa efek Indonesia", fakultas ekonomi Unud, Bali
} 
Dinda Dwi W, Lu'Lu'Il Maknuun, Ahmad Mukhlisuddin : Pengaruh Fundamental Makro...

terjadinya bencana alam, force majeur dan pandemi seperti ini. Dengan itu auditor akan mempertimbankan apabila terjadinya masalah atas kelangsungan usaha perusahaan.

Peryataan ini di dukung dengan teori Auditor bahwa "bentuk penilaian opini auditor menggunakan laporan keuangan dengan mempertimbangkan keputusan ekonomi, dengan begitu informasi audit laporan keuangan perusahaan sangat penting bagi pengguna laporan keuangan" 47 . Hasil penelitian ini sejalan dengan penelitian yang dilakukan olehHwihanus, H., \& Yuhertiana, I. Yang menyatakan bahwa fundamental makro berpengaruh positif signifikan terhadap Audit Opinion Going Concern karena keadaaan ekonomi yang terjadi di Indonesia akan mempengaruhi auditor dalam mempertimbankan penilaian asumsi atas kelangsungan usaha perusahaan ${ }^{48}$.

3. H3: pengaruh Islamic Coorporate Social Responsibility terhadap Audit Opinion Going Concern.

Berdasarkan hasil analisis data tabel 4.12 pada hubungan variabel Islamic Coorporate Social Responsibility terhadap Audit Opinion Going Concern terdapat pengaruh negative signifikan sehingga menunjukan ditolaknya $\mathrm{H}_{3}$. Dengan hasil ini menunjukan bahwa pengungkapan tangung jawab sosial tidak akan mempengaruhi auditor dalam mempertimbangkan asumsi opini atas kelangsungan usaha perusahaan, karena pada dasarnya auditor hanya memeperhitungan nilai material perusahaan atas kelangsungan usahanya bukan menilai tanggung jawab sosial yang dilaksanakan oleh perusahaan.

Kegiatan tanggung jawab sosial ialah sudah menjadi tugas dan kewajiban yang ditetapkan oleh pemerintah sebagai bentuk imbal balik perusahaan karna sudah menggunakanya sebagai produksi. Dengan itu auditor tidak memepertimbangkan kegiatan tanggung jawab sosial sebagai pemberian asumsi atau opini pada perusahaan.

Adapun hubungan signifikan yang negative tersebut menimbulkan beberapa faktor, diantaranya yaitu:

a. Bank syariah di Indonesia belum sepenuhnya mengungkapkan program tanggungjawab sosial secara islam

b. Pengungkapan tanggung jawab sosial yang diungkapkan oleh bank syariah masih dalam bentuk yang relatif sederhana.

c. Pengungkapan dengan tema indeks ISR yang dikembangkan oleh Haniffa dan Othman et.al dengan tema keuangan \& investasi, produk dan jasa masih sangat rendah yang seharusnya pada industri perbankan syariah pengungkapan kegiatan tersebut harus memiliki nilai yang besar. Karena pada kedua tema tersebut terdapat unsur pengungkapan gharar, riba dan maysir pada kegiatan keuangan \& investasi.

d. Meskipun begitu, bank syariah secara menyeluruh setiap tahunya sudah mampu menunjukan peningkatan yang baik dalam kegiatan sosialnya. Hal ini ditunjukan

\footnotetext{
${ }^{47}$ Rachman Anita, Afifudin, Mawardi M Cholid, Pengaruh likuiditas dan pertumbuhan perusaahaan terhadap opini audit going concern, (Malang, FEB Universitas Islam Malang,2020)

${ }^{48}$ Hwihanus, H., \& Yuhertiana, I, "Audit Opinion: Model Value of the Firm State-Owned Business Enterprises Indonesia”, Management Studies, 2019.
} 
Dinda Dwi W, Lu'Lu'Il Maknuun, Ahmad Mukhlisuddin : Pengaruh Fundamental Makro...

dengan meningkatnya jumlah dana yang dikeluarkan untuk keseluruhan bidang pada setiap program ICSR yang dipaparkan dalam annual report bank syariah.

Hasil penelitian ini berbeda dengan penelitian sebelumnya yang dilakukan oleh Hwihanus, H., Ratnawati, T., \& Yuhertiana, I. yang menyatakan bahwa terdapat pengaruh positif signifikan pada hubungan Islamic Coorporate Social Responsibility terhadap Audit Opinion Going Concern ${ }^{49}$.

4. H4: pengaruh Islamic Coorporate Social Responsibility terhadap Value Of the Firm.

Berdasarkan hasil analisis data tabel 4.12 pada hubungan variabel Islamic Coorporate Social Responsibility terhadap Value of the Firm. Terdapat hubungan positifsignifikan, sehingga menunjukan bahwa H4 diterima. Dengan hasil ini menunjukan bahwa kegiatan sosial yang dilakukan oleh perusahaan akan mendapatkan persepi atau nilai yang bagus bagi masyarakat, investor dan negara.

Dalam teori stakeholder digambarkan bahwasanya keberlangsungan perusahaan dipengaruhi oleh pihak stakeholder. Dengan teori tersebut para investor mengharapkan perusahaan dapat memberikan imbalan balik atas investasinya. Salah satu imbalan balik dapat berupa return saham, dividen dan perlaksanaan ICSR yang diungkapkan dalam laporan keuangan tahunan. Pengungkapan ICSR yang ungkapakan ialah yang sesuai dengan pasal 66 dan pasal 74 Undang-Undang No 40 tahun 2007 tentang perseroan terbatas yang memiliki kewajiban untuk melakukan tangung jawab islam sosial dan lingkungan. Pengungkapan ICSR dapat menyampaikan informasi kepada stakeholder untuk meluruskan visi, misi perusahaan dengan prkatik dan kegiatan bisnis perusahaan. dengan pengungkapan tersebut perusahaan akan mendapatkan kepercayaan oleh stakeholder dengan itu nilai perusahaan akan semakin dinilai baik oleh investor

Hasil penelitian ini berbeda dengan penelitian sebelumnya yang dilakukan oleh A'inur Rohmah yang menyatakan bahwa terdapat pengaruh negative signifikan pada hubungan Islamic Corporate Governance terhadap nilai perusahaan.

\section{H5: pengaruh Audit Opinion Going Concern terhadap Value Of the Firm.}

Berdasarkan hasil analisis data tabel 4.12 pada hubungan variabel Audit Opinion Going Concern terhadap Value of the Firm terdapat pengaruh positif signifikan, dengan ini menyarakan bahwa H5 diterima. Dengan hasil ini menunjukan bahwa Audit Opinion Going Concern merupakan penilaian yang penting bagi perusahaan dalam membangun citra terhadap investor dan masyarakat, serta dapat menjadikan pertimbangan bagi para investor dalam memutuskan kegiatan investasinya pada sebuah perusahaan. Berdasarkan itu juga, auditor dapat memberikan persepi dan penilaian kepada perusahaan, penilaian tersebut akan memberikan dampak atau pengaruh yang besar pada keputusan investor dalam menilai perusahaan tersebut. Dengan itu pengaruh hubungan ini merupakan hubungan yang positif.

\footnotetext{
${ }^{49}$ Hwihanus, H., Ratnawati, T., \& Yuhertiana, I. (2018). Analysis of the Influence of Fundamental Macro and Fundamental Micro to Discolure of Corporate Social Responsibility, Ownership Structure, Financial Performance, Going Concern Audit Opinion and Value of the Firm at State-Owned Enterprises in Indonesia. Archives of Business Research, 6(7), 66-77.
} 
Dinda Dwi W, Lu'Lu'Il Maknuun, Ahmad Mukhlisuddin : Pengaruh Fundamental Makro...

Sesuai dengan fungsinya auditor melakukan monitoring atas pekerjaan manajer melalui laporan keuangaan, sehingga auditor melakukan tahapan audit pada kewajaran laporan keuangan yang terdiri dari neraca, laporan laba rugi, laporan perubahan modal dan laporan arus kas termasuk catatan atas laporan keuangan yang kemudian diberikan kesimpulan penilaian dalam bentuk opini audit. Dengan pendapat auditor yang mudah disampaikan kepada investor, maka investor mempercayai auditor sebagai pihak independent yang memberikan pendapat terhadap perusahaan. dengan ini menunjukan bahwa investor dalam mempertimbakan keputusan investasinya meninjau peryataan auditor. Dan nilai perusahaan dapat meningkat apabila terdapat pendapat positif yang dinaytakan oleh auditor. Hal ini menunjukan terdapatnya pengaruh positif signifikan antara auditor terhadap nilai perusahaan.

Hasil penelitian ini sesuai dengan penelitian yang dilakukan oleh Hwihanus, $\mathrm{H}$., Ratnawati, T., \& Yuhertiana, I. yang menyatakan bahwa terdapat pengaruh positif signifikan pada hubungan AOGC terhadap nilai perusahaan ${ }^{50}$.

\section{E.Kesimpulan}

Berdasarkan analisis data yang telah dilakukan sebelumnya, dapat disimpulkan bahwa hamper keseluruhuan hipotesis penelitian dapat diterima yang ditunjukan dengan tingkat signifikansi lever 5\% dan t-tabel $>1,96$. Kecuali hubungan variabel Islamic corporate social responsibility terhadap audit opinion going concern yang menunjukan nilai statistic sebesar $1.027(>1,96)$ dengan itu menyatakan bahwa hipotesis H3 ditolak .

\section{Daftar Pustaka}

\section{Buku}

Edi Purwanto, Metode Penelitian Kuantitatif (Semarang: Fakultas Ilmu Pendidikan Universitas Negeri Semarang, 2013), 68

Harahap Sofyan S, Wiroso, Yusuf Muhamad, Akutansi Perbankan Syariah, LPFE Usakti, (Jakarta:cetakan keempat, 2010).

Harmono, Manajemen Keuangan berbasis balanced, (Jakarta:Pt Bumi Angkasa Raya, 2015) Indrayati, Pengauditan (Audit Laporan Keuangan), (Malang, Aditya Media Publishing:2017) Kasmir, Bank dan Lembaga keuangan Syariah, (Jakarta: PT. Raja Grafindo Persada, 2009), Hal 24

Mariyadi Agusm Wicaksono Bintoro Tri, Lingkungan Ekonomi, Binus University Business School,2018

Mulyadi, Mannan Salam, Modul Auditing, (Jakarta, Universitas Terbuka: 2008)

N.G. Mankiw, Pengantar Ekonomi Makro, Edisi 3, terjemahan, Jakarta:Salemba Empat 2006.

\footnotetext{
${ }^{50}$ Hwihanus, H., Ratnawati, T., \& Yuhertiana, I. (2018). Analysis of the Influence of Fundamental Macro and Fundamental Micro to Discolure of Corporate Social Responsibility, Ownership Structure, Financial Performance, Going Concern Audit Opinion and Value of the Firm at State-Owned Enterprises in Indonesia. Archives of Business Research, 6(7), 66-77.
} 
Dinda Dwi W, Lu'Lu'Il Maknuun, Ahmad Mukhlisuddin : Pengaruh Fundamental Makro...

Sugiyono, Metode penelitian Kuantitatif, Kualitatif, dan R\&D, Bandung, Alfabeta, 2008.

Sinarwati Ni Kadek, Mengapa perusahaan menerima opini audit going concern, 2017

Sujianto Agus Eko, Sukarsono, Masrokan Prim, Studi Empiris Pada negara-negara Di ASEAN terpilih, (Jawa Timur: STAIN Tulungagung Press: 2012)

Wahyuddin, Islamic Coorporate Social Resposibilty (ICSR); Kajian Teoritis, Wiroso, "Pengantar Akutansi Syariah", IAI, Akutansi Lembaga Keuangan Syariah, 2013.

Jurnal

Anuraga Ganga, Edy Sulistiyawan, Munadhiroh Siti, "structural equation modeling - partial least square untuk pemodelan indeks pembangunan kesehatan masyarakat (ipkm) di jawa timur, Universitas Airlangga, 2017

Amalia, Resya Rizkiy. Pengaruh Faktor-Faktor Fundamental dan Variabel Makro Ekonomi Terhadap Return Saham (Studi Empiris pada perusahaan consumer goods sub sector Food and Beverages yang tedaftar di BEI 2014-206), Uniersitas Islam Indonesia, 2018

Ayu Dea Putri, Suarjaya Gede, Pengaruh profitabilitas terhadap nilai perusahaan dengan corporate social responsibility sebagai variabel mediasi pada perusahaan pertambangan, Junal Manajemen Unud, 2017.

Darus Faizah, Yusoff Haslinda, Abang Naim Dayang Milianna, Zaim Mustaffa Mohamed, Islamic Coorporate Social Responsibilty Framework form the Perspective of Maqasid al-Syariah and Maslahah,(Universitas Sains Malaysia,2013)

Dwipartha Ni Made With a, "Pengaruh faktor ekonomi makro dan kinerja keuangan terhadap nilai perusahaan manufaktur di bursa efek Indonesia", fakultas ekonomi Unud, Bali.

Hwihanus, H., Ratnawati, T., \& Yuhertiana, I. (2018). Analysis of the Influence of Fundamental Macro and Fundamental Micro to Discolure of Corporate Social Responsibility, Ownership Structure, Financial Performance, Going Concern Audit Opinion and Value of the Firm at State-Owned Enterprises in Indonesia. Archives of Business Research, 6(7), 66-77.

Hwihanus, H., \& Yuhertiana, I, “Audit Opinion: Model Value of the Firm State-Owned Business Enterprises Indonesia”, Management Studies, 2019.

Kementrian Koordinator Bidang Perekonomian Republik Indonesia, "Outlook Perekonomian Indonesia, Pemulihan dan Transformasi Ekonomi Naional“, 2020

Siringorunggo Renniwaty, Pratiwi Rahmni, Pengukuran tingkat profitabilitas perbankan syariah indonesia dengan menggunakan rasio camel periode 2012-2016, 2018.1

Rachman Anita, Afifudin, Mawardi M Cholid, Pengaruh likuiditas dan pertumbuhan perusaahaan terhadap opini audit going concern, (Malang, FEB Universitas Islam Malang,2020) 